\title{
Organizational Resilience: How does it Fit with the Principles of a Learning Organization?
}

\begin{abstract}
The article discusses the possibilities of the resilience of organizations in the context of a learning organization and presents the results of a survey of the leaders of regional public organizations, on the basis of which the factors of the resilience of organizations are ranked according to importance. The study results have revealed that NGOs further away from regional centres tend to focus on routine management aspects, enabling the members of the organization to communicate and collaborate effectively, meanwhile the development of the members, an essential resilience factor, was not considered as highly important.
\end{abstract}

Keywords: learning organizations, resilience, factors.

Straipsnyje aptariamos organizacijų atsparumo galimybės besimokančios organizacijos kontekste bei pristatomi regioninių nevyriausybinių organizacijų vadovų apklausos rezultatai, kurių pagrindu organizacijų atsparumo veiksniai ranguojami pagal svarbą. Tyrimo rezultatai atskleidè, kad nuo regionų centrų nutolusios NVO labiau linkusios rūpintis rutininiais vadybiniais aspektais, ̣galinančiais organizacijos narius veiksmingai bendrauti ir bendradarbiauti, o svarbiam organizacinio atsparumo veiksniui - organizacijos narių tobulinimui(uisi) - NVO vadovai linkę teikti vieną iš mažiausių prioritetų.

Raktiniai žodžiai: besimokančios organizacijos, atsparumas, veiksniai.

\section{Introduction}

Due to the constantly changing business environment, shifting consumer needs, etc., state, business and public organizations need to change and improve their activities as well as improve organizational management (Fraussen, Halpin, 2017). However, adapting to change alone is no longer sufficient for organizations to cope with extremely difficult contingencies and those who are able to learn faster than competitors and make more efficient use of their available resources, especially intellectuals, gain a competitive advantage.

Research shows that learning improves problem-solving skills, changes the actions, knowledge, understanding, attitudes, and attitudes of members of an organization, and fosters the development

Jolita GEČIENĖ - affiliated lecturer at Mykolas Romeris University, Institute of Leadership and Strategic Management. Address: Ateities str. 20, LT-08303, Vilnius, Lithuania. Phone: +370 614 58926. E-mail: geciene.j@mruni.eu

Agota Giedré RAIŠIENÉ - professor at Mykolas Romeris University, Institute of Leadership and Strategic Management. Address: Ateities str. 20, LT-08303, Vilnius, Lithuania. Phone: +370 698 73190. E-mail: agotar@mruni.eu 
of new skills to gain an advantage over other organizations and ensure organizational resilience in crises (Senge et al., 2000). Characteristics of a learning organization can be attributed to many modern organizations; however, the quality and intensity of learning become the decisive criteria that create the conditions not only to survive in a dynamic environment but also to plan successful activities over time. Moreover, any organization seeking to overcome crises and unexpected changes must become a learner, i.e. one that works in a targeted way has a good understanding of the current situation, dynamics and market situation, plans flexibly, overcomes challenges, and purposefully strengthens its resilience.

On the other hand, constant global socio-economic change is becoming a challenge not only for individual organizations and their resilience but also to the sustainability of regions and the state as a whole. The White Paper on Regional Policy (2017) identifies inclusive, empowered and competent regions as one of the pillars of Lithuania's regional policy. In turn, municipal institutions, establishments, small, medium and large businesses from Lithuania and abroad are considered important implementers of regional policy.

It must be emphasized that the sustainability of the state depends on the viability and sustainability of the regions, which primarily presupposes the resilience of the organizations operating in the regions. However, in the event of unforeseen difficulties, policymakers focus on regional centers and the organizations that operate within them, especially large ones. The latter are considered critical to the national economy as they have more advantages: experience in the adoption of innovation and potential for expanding markets. Meanwhile, for organizations away from regional centres, i.e. located in district municipalities, rural areas, receive less state attention and support. As a result, organizations away from regional centres are not so well placed in dealing with the problems that have arisen. Due to the specifics of the activity and the resources of robots, non-governmental, non-profit organizations (NGOs) find themselves in an even more difficult situation during periods of instability. Thus, strengthening their resilience is both crucial and a much more challenging task compared to business organizations.

The topic of organizational resilience is developed quite widely in scientific publications, nevertheless, the answer to the question of what the key factors of organizational resilience in NGOs are is, it remains unclear. So, our study sought to at least partially fill this gap.

Defining the resilience of organizations as the research object, we set the following aim of the research - by interviewing the leaders of NGOs operating in district municipalities (not of major cities) and rural areas of Lithuania, to determine which organizational resilience factors they consider to be the most important. Since the concept of organizational resilience is inseparable from the concept of learning, we examined the results of the survey in the context of a learning organization.

The research methods: a questionnaire survey of respondents, descriptive statistics, relative importance index (RII) method.

The objectives of the article - to present the specifics of NGOs in the context of types of organizations, to discuss the 
links between organizational resilience and the learning organization, to present the results of the survey of leaders of regional NGOs, and based on the results of the survey, to identify the factors of organizational resilience in terms of relative importance.

\section{Types of organizations operating in the regions}

Opportunities for organizational development depend in part on the peculiarities of geographical location. Organizations operating in regional centres often have a greater focus on competitive advantage through technology and innovation and the expansion of markets for services and goods beyond the city, region and country. Meanwhile, the development of organizations operating in areas far removed from regional centers is focused on the needs of local people and the use of local resources (Haggblade et al., 2007; Pakalniené, 2015). S. Haggblade et al. (2007) found that managers and employees of organizations away from regional centres are more likely to devote their energy, time, and other resources to solving problematic issues, thus strengthening the resilience of organizations.

As regards the types of organizations, it can be noted that the classification of organizations allows to bring together the organizations which are similar in one or several characteristics and thus facilitate the solution of some economic and organizational issues, overcoming critical situations, as well as provide generalized recommendations for increasing organizational resilience.
J. E. Austin, (2010) found that matching the different competencies and resources of organizations is a key factor in solving complex, large-scale problems that single organizations are unable to address. In a similar type of organization, there is an opportunity to apply typical solutions in various areas: engineering, technology, production, management, accounting, etc. It is common to classify organizations according to the following characteristics:

1. By size, i.e. divided into micro-enterprises, small, medium and large organizations;

2. According to the nature of activity, i.e. trade, production, etc.;

3. According to the form of ownership private, non-governmental, state;

4. By sector, i.e. public, private, and nongovernmental sector organizations;

5. Under subordination, such as state and municipal enterprises;

6. In terms of profit, i.e. business organizations, state organizations, NGOs, hybrid organizations (social enterprises). The development of the modern public sector is determined by the changes taking place in the world, related not only to the growing population but also to the economic and management peculiarities of social change and increasing opportunities for knowledge and information (Lane, 2000). Factors influencing the activities of public organizations differ from the conditions and factors of efficiency of the private and NGO sector because public sector organizations operate in a different structural environment, their functions are officially approved, their activities are much more open to public control, there are specific rules and procedures regulated and constrained by the state's financial 
capacity, and constrained by regulations, all of which limit operational flexibility, empowerment, delegation, local initiative, and decision-making (Wholey, 1983). In the private and NGO sectors, activities are much freer than in the state, they are not restricted by specific laws or regulations, in uncertain situations, the activities of the organization are formed according to the circumstances. Partnerships between private organizations and state, municipal organizations, and public actors such as NGOs are gaining in importance around the world (Reed and Reed, 2009).

Smaller organizations away from regional centres are more likely to innovate in areas related to the development and improvement of products and services, organizational innovation. Such organizations are flexible, they can respond quickly to rapid changes in technology and customer needs, overcome challenges, sudden difficulties and unfavourable situations (Gineitienè and Girdenis, 2004).

Smaller organizations operating further away from regional centres are more likely to promote innovations related to the development and improvement of products and services, organizational innovation. Such organizations are flexible, they can respond quickly to rapid changes in technology and customer needs, overcome challenges, sudden difficulties and unfavourable situations (Gineitienè and Girdenis, 2004).

The main differences between the activities of public and private organizations are the performance of functions and their number, as well as the distribution of responsibilities (Public Audit Report of the National Audit Office, 2008). Meanwhile, non-governmental organizations, mediating between the public and private sectors, include all civic organizations established of the free will of citizens, bringing together persons or groups of similar interests (Šilinkskytè, 2013).

The NGO Development Concept (2010) defines the activities of non-governmental organizations as autonomous, independent from authority and business, operating on a voluntary basis, a non-profit, legal entity established in Lithuania for the benefit of society. In the international classification of organizations, NGOs are divided into 12 groups according to their fields of activity: culture and recreation; education and research; health protection; social services; environmental protection; development and housing; law; advocacy and politics; development of philanthropy and volunteering; international law; religion; business and professional organizations (Recommendation CM / Rec, 2007).

Unable to allocate the necessary resources and to deal with emergencies and issues on their own, public authorities outsource these functions to other sectors. For this reason, when we compare the activity of NGOs and the private sector organizations, despite the similarities of their activities, due to the differences in their functions as well as differences in organizational structure, we can highlight these advantages contributing to the organizational resilience:

1. Access to unpaid work - people tend to spend their free time working in non-profit organizations;

2. Access to gratuitous support - nonprofit organizations do not aim for personal material benefits, unlike private organizations, can expect to receive support from those who find the aims of the non-profit organization acceptable. 
NGOs, like other organizations, face long-term challenges when operating in an ever-changing environment with unforeseen changes or shocks (Birch and Mykhnenko, 2009). Organizations need adaptability, skills development, and lifelong learning to meet challenges and strengthen organizational resilience (Grabher and Stark, 1997).

\section{Organizational resilience in the context of learning organizations}

In today's environment of information technology and organizational reform development, synergies between knowledge, experience, policy understanding and decision-making involving public and private sector companies, while involving management improvement and public organizations, are necessary to overcome unforeseen changes and strengthen organizational resilience (Raipa, 2009). The learning strategy at the individual and institutional level in all areas of public and private life is defined by the Lifelong Learning Memorandum (2001). The world countries are assessed on the basis of the level of science, technology and innovation rather than available capital or natural resources Gineitienè and Girdenis, 2004). More recently, training has been seen as an activity that takes place throughout a person's working life, rather than as a onetime process at the beginning of working life to acquire a specialty or profession (Jewell, 2002). These days, knowledge is gaining a distinct role in society as the postmodern development environment changes, so does the role and behaviour of organizations, and learning organizations are gaining an increasing advantage
(Probst et al., 2006). To overcome unforeseen situations, crises and shocks, organizations need to learn to adapt to change and changing social responsibility needs (Bass, 2000). Organizational learning, which enables the organization and its members to absorb new knowledge, adapt to the changing environment and make decisions, manifests itself not only in improving the individual knowledge of the organization's employees but also in improving forms of interaction and coordination (Jucevičius, 2007). Skills and knowledge allow organizations to adapt to contingencies without disrupting the entire system, using existing knowledge to make important decisions in the right situation and strengthen the resilience of the organization (Grabher and Stark, 1997). A learning organization ensures the ability to respond flexibly and effectively to environmental changes, crises, unfavourable circumstances, to strengthen organizational resilience and to develop members of the organization who are able to consistently participate in the continuous learning process (Pundzienè, 2002). B. Simonaitiene (2003) states that with constantly changing knowledge, the ability of an individual and organizations to learn to assimilate new ideas, apply them in action faster than competitors, has a direct impact on competitive advantage, recovery from shocks, development and survival in the market. Therefore, many authors identify the ability to select and use the required information, the flows of which have been very high recently, as a relevant challenge for contemporary organizations (Probst et al., 2006). N. Longworth, (2018) notes that an essential feature of a learning organization is learning through activity, where learning takes place by 
reflecting and changing one's practice, thereby creating opportunities for new experiences and learning. The rapidly changing world of practice forces everyone to learn, meanwhile learning provides new insights which serve to change practice. It becomes difficult to distinguish where learning ends and activities begin, where activities end and learning begins (Simonaitienè, 2003; Longworth, 2018). Other scholars argue that strengthening the resilience of organizations requires correcting past mistakes and insights into the future, and thus distinguishes between two types of organizational learning:

1. Adaptive learning - it is focused on the past, i.e. directed to clarify the situation that happened in the past, to correct mistakes and change the behaviour.

2. Generative learning - it is focused on the future, insight into ideas and search for problems, thus creating opportunities and preconditions to influence changes in the environment (Senge, 1999; Smith, 2001).

All organizations learn in one aspect or another, but the impact of knowledge is revealed when knowledge is constantly updated and shared, therefore the productivity and competitiveness of learning organizations increase due to the effect of learning and knowledge sharing, which enables to create new plans, to overcome obstacles and develop activities (Brown and Duguid, 2004). Organizations seeking to reinforce resilience, overcome adversity, survive and grow must pursue a pace of learning enabling them to outpace the changes in the environment (Garatt, 1987). Such an organization has accumulated competence to create, acquire, and transfer knowledge, as well as to change behaviour, by rapidly adapting to new knowledge and perceptions (Garvin, 1993).

To substantiate the advantage of learning organizations in terms of their resilience, G. Morgan (1998) presents the main aspects of these organizations:

1. Theories of action are implemented and formulated, which enable organizations to implement various tasks, creating certain levels of possible factors, identifying the main methods of action, tools and ways to perform these actions;

2. Two types of action theories are implemented:

- general theory of action - formal and codified, according to which the organizations present itself publicly, both to external and internal members of the organization, this theory is useful for the organization itself in analysing past learning and experience, training new members;

- informal theory of action - reveals itself in the actions and behaviours of the organization and its members, provides a basis for the individual's action and shows how that action relates to the actions of other members of the organization; this theory is completely informal, implicit and often uncodified; it is related to the individuality of members of organizations, individual gained experience and created knowledge.

Every organization needs to continually develop, test, and review its actions in order to learn and adapt to a changing environment and thus to take a form of resilience based on preconceived 
successful development. Organizational resilience helps to explain how different organizational elements can adapt to acquire a stronger form of resilience at any point (Bluestone and Harron, 1982). F. H. Norris et al. (2008) note that the resilience of learning organizations is the ability to maintain a balance between different elements in a crisis situation by concentrating available resources and competencies, the ability to manage the needs, challenges, and changes they face.

An analysis of the scientific literature reveals that only learning organizations can survive in a changing environment, as lifelong learning becomes an essential factor in organizational survival and ensures successful adaptation to a rapidly changing environment.

\section{Factors of organizational resilience in theoretical terms}

Organizational resilience is understood as an ability and process rather than an outcome, and as adaptability rather than stability (Pfefferbaum et al., 2005). Highly resilient organizations are able to ensure prospective development and development of business processes, prepare for unplanned external changes in the changing environment and understand them more deeply, as well as more purposefully choose measures to overcome emerging external environmental threats and challenges (Gečienė and Raišienè, 2019).

Adapting to changed conditions requires an understanding of change and the ability to create and apply new business models and reshape processes. This, in turn, requires improvement both at the individual level of employees and across the organization. Learning organizations have many advantages over nonlearning and non-staffing organizations (Simonaitiené, 2003). An organization which learns and adapts to change have the following features:

- changes the scope of its activities and focuses on its core business;

- redefines internal structural units;

- increases decision-making speed through the use of advanced information technology;

- seeks to use the knowledge and energy of its employees in ways that have not been tested before;

- connects people working in different parts of the organization to facilitate the coordination of work and learning; - replaces vertical, hierarchical relationships with more horizontal ones (Ginevičiaus et al., 2006).

Organizations operate in a closely interconnected and interactively complex world of unexpected, adverse events, emergencies, and crises (Rosset and Martínez-Torres, 2012). Organizational resilience factors are formed in order for organizations to successfully cope with unexpected situations (Magis, 2010). It is important to collaborate with other organizations when implementing and planning the processes of change, considering the limits of their existing constraints, developing new growth pathways to compensate for adverse events and processes of decline and strengthening the resilience of organizations within organizations (Swanstrom, 2008).

To adapt to changed conditions it is crucial to perceive the change and to be able to create, as well as implement new activity models and reform processes. Accordingly, it is essential to develop on an 
individual scale, as well as on an organizational one. Learning organizations possess many advantages over non-learning and non-strafing organization.

Seeking to overcome challenges, difficulties and crises, as well as to protect against adverse events, the key elements of organizational resilience are singled out: social and economic justice; common good; effective risk management; integration of governmental and non-governmental organizations and communication factors (Chandra et al., 2013). J. Gečienè and A. G. Raišiene (2019) note that an organization's readiness to adapt and continue to operate in adverse circumstances is related to management decisions, which include: the organization's internal policies and processes, affecting the organizational, human resource management and leadership characteristics; external policies and processes of an organization that determine the potential and opportunities for inter-organizational cooperation and mutual support; strategic choice to actively or proactively and taking into account the conditions of the external environment.

As research (e.g., Wolfe, 2010; Bristow and Healey 2013; Williams et al., 2013) shows, developing organizations' resilience requires progress at all three levels:

- procedural - processes are improved allowing to implement changes;

- hierarchical - leaders who are able to initiate and organize change are trained;

- interactions - provides feedback in interactions with other organizations, i.e. change and adaptability are developed at different levels and with different speed potentials. Meanwhile, the research of J. Gečienė and A. Raišienè
(2019) found that to increase the resilience of organizations, such actions are important as: the use of human resources; promoting personal leadership and involving employees in decision-making; employee motivation; fostering optimism and faith in one's organization; unity, teamwork and cooperation; common goal; communication culture and work atmosphere; inter-institutional cooperation; effective application of innovations; having a crisis management plan, risk refinement and strategic thinking in solving problems; periodic activity analysis; honesty and responsibility.

J. Gečienè and A. Raišienė (2019) distinguish the following factors of organizational resilience based on research:

- Empowering leadership and human resource management for maximum performance;

- Protection of technology and telecommunications systems to reduce the effects of disruption;

- Regular assessment, identification and management of risks and crises in the organization;

- Organizational culture that promotes the organisation's resilience to adverse conditions;

- Interinstitutional cooperation;

- Strategic planning, operational optimization and continuous improvement;

- Management of business continuity processes;

- Innovation and proactivity, improvement of knowledge and competencies;

- Financial management that ensures the financial stability of the organization.

Meanwhile, the research conducted by J. Gečiene (2020) allowed highlighting the most important factors of organizational 
resilience in the period of extreme situations. The research reveals that in the period of emergencies, in order to preserve the continuity of the organization and the successful existence of the organization, it is very important to follow the resolutions of the Government, the Ministry of Health, and the recommendations of municipal emergency commissions. The heads of organizations need to ensure the implementation of prevention measures in the institution. The factors of organizational resilience identified by J. Gečienè (2019) are:

- human resource management, which allows to achieve efficient performance results;

- standardized risk management procedures, identified as a tool for crisis management;

- strategic planning, which allows to strategically plan the activities of the organization and maintain stability.

Finally, when analysing NGOs in particular, R. Boschma and G. Capone (2014) note that to significantly strengthen their organizational resilience, NGOs should focus on developing the skills of their members and building the base of their specialized knowledge seeking to diversify new related activities and to connect to other organizations in order to link resources and thus to associate with them.

As can be seen, the concept of organizational resilience has unambiguous links to the concept of a learning organization.

\section{Research methodology}

Participants and procedure. To examine the key organization resilience factors in the context of learning organizations the managers of NGO sector organizations were approached to participate in the study. The survey was sent to Lithuanian municipalities with a request to share the survey questionnaire with the heads of non-governmental organizations. Rural and (non-large city) district municipalities were selected for the study. In total, 347 managers of NGOs took part in the study. Data were collected via a webbased survey. The data of the survey was processed using the program IBM SPSS Statistics. All participants were informed about the purpose of the study. Participation was voluntary and the respondents were assured of the confidentiality of their response.

Table 1 shows the attributes of the respondents, where $62 \% \quad(\mathrm{~N}=215)$ of respondents were female and $38 \%$ $(\mathrm{N}=132)$ - males. In terms of age groups, the respondents aged from 18 to 25 comprised $9,2 \%$ of the total, those from 26 to 35 years $-27,1 \%$, from 36 to 45 years $36,3 \%$, from 46 to 55 years $-13,3 \%$ and those over 55 years - 14,1\%.

Demographics reveal that middleaged (26-45) women are more involved in society.

Data analysis. The collected data was analysed through the RII method. This method allows to identify most of the important criteria based on participants' replies and it is also an appropriate tool to prioritize indicators rated on Likert type scales.

\section{Research results}

The contribution of each of the factor to the overall resilience of organization was examined and the ranking of the 
Table 1. Socio-demographic characteristics

\begin{tabular}{|cccc|}
\hline Variable & & $\mathbf{N}$ & $\%$ \\
\hline Gender & Female & 215 & 62 \\
& Male & 132 & 38 \\
\hline Age & $18-25$ & 32 & 9,2 \\
& $26-35$ & 94 & 27,1 \\
& $36-45$ & 126 & 36,3 \\
& $46-55$ & 46 & 13,3 \\
& $>55$ & 49 & 14,1 \\
\hline Total & 347 & & 100 \\
\hline
\end{tabular}

Source: the authors' results.

attributes in terms of their criticality as perceived by the respondents was done by use of Relative Importance Index (RII) which was computed using an equation and the results of the analysis are presented in Table 2.

$$
\begin{aligned}
& \mathrm{RII}=\mathrm{W} / \mathrm{A} * \mathrm{~N}(0 \leq \mathrm{RII} \leq 1) \\
& \text { Where: }
\end{aligned}
$$

$\mathrm{W}$ - is the weight given to each factor by the respondents and ranges from 1 to 10 , (where " 1 " is "not important at all" and " 5 " is "absolutely essential");

$\mathrm{A}$ - is the highest weight (i.e. 10 in this case);

$\mathrm{N}$ - is the total number of respondents.
The survey data shows that participants are competent to answer survey questions accurately because, for many years, they are actively involved in the organization's activities, which is important to ensure an organization's resilience.

The organizational resilience factors scale consisted of 12 items: resilience factors (e.g. "Attention to quality assurance of organization activities", "Care for organization members' motivation and activity satisfaction"). The survey participants were offered a closed type questionnaire and asked to express their opinion on a 10 -point Likert-type scale $(1=$ "Not

Table 2. Length of membership and organizational size

\begin{tabular}{|l|c|c|c|}
\hline Variable & \multicolumn{2}{|c|}{$\mathbf{N}$} & \% \\
\hline \multirow{4}{*}{$\begin{array}{l}\text { How long are you a member of } \\
\text { the organization? }\end{array}$} & $<1$ & 34 & 9,8 \\
\cline { 2 - 4 } & $1-3$ & 42 & 12,1 \\
\cline { 2 - 4 } & $4-10$ & 163 & 31,3 \\
\hline \multirow{3}{*}{$\begin{array}{l}\text { What is the number of your } \\
\text { organization members? }\end{array}$} & $>10$ & 108 & 2,3 \\
\cline { 2 - 4 } & $<10$ & 8 & 28 \\
\cline { 2 - 4 } & $11-49$ & 172 & 49,6 \\
\hline Total & $50-249$ & 70 & 20,2 \\
\hline
\end{tabular}

Source: the authors' results. 
Table 3. Relative importance indexes of resilience factors

\begin{tabular}{|c|lcc|}
\hline No. & \multicolumn{1}{|c}{ Item } & \multicolumn{1}{|c}{ RII } & Rank \\
\hline 1. & Seeking for a common agreement on how to improve organization performance & 0,938 & 1 \\
\hline 2. & Involving members in decision-making in the organization & 0,930 & 2 \\
\hline 3. & Including project members in decision making within projects & 0,915 & 3 \\
\hline 4. & $\begin{array}{l}\text { Keeping organization members informed of necessary changes and project } \\
\text { opportunities }\end{array}$ & 0,905 & 4 \\
\hline 5. & Care for organization members' motivation and activity satisfaction & 0,902 \\
\hline 6. & $\begin{array}{l}\text { Being guided by real situation assessment-based solutions in improving the results of } \\
\text { organization activities }\end{array}$ & 0,900 & 6 \\
\hline 7. & Attention to organization vision, mission and values & 0,891 & 7 \\
\hline 8. & Attention to quality assurance of organization activities & 0,882 & 8 \\
\hline 9 & Deep understanding of the work being performed & 0,856 & 9 \\
\hline 10. & Attention to project participants' professional development. & 0,820 & 10 \\
\hline 11. & Attention to observing the rules for common activities & 0,809 & 11 \\
\hline 12. & Attention to organization members' health and safety requirements. & 0,787 & 12 \\
\hline
\end{tabular}

Source: the authors' results.

important at all" to $10=$ "Absolutely essential"). The reliability coefficient Cronbach alpha of the scale was 0.767.

To determine the key organizational resilience factors, the Relative Importance Index (RII) was used in the study.

The research revealed that the most important factors for NGOs to strengthen resilience are: consensus to improve performance, the involvement of members in the decision-making process, sharing of information about change, and motivation of members of the organization. Although other organizational resilience factors were ranked below 5, as shown by the relative significance index RII, those factors are: performance improvement, vision, mission and values, performance quality, professional development performance rules, safety and health are also important to ensure the resilience of the organization.

\section{Conclusions}

Organizations operating in the areas removed from regional centres focus on the needs of the local population and the use of local resources, and in this regard, their socio-economic role is clear. Unfortunately, resource-related constraints make it rather difficult for regional small and especially non-profit organizations to adequately address organizational resilience, although being resilient and successful, they make a significant contribution to regional viability and sustainability.

Examining the resilience of organizations in the context of a learning organization has shown that in order to overcome unforeseen situations, crises and shocks, organizations need to learn to adapt to change and to changing needs of the social environment, and this requires the 
knowledge that organizations can only acquire through lifelong learning.

The study found that NGOs further away from regional centres tend to take care of aspects that enable members to communicate and collaborate effectively in pursuance of achieving NGO performance results to withstand complex contingencies and crisis situations. Based on the study, the following resistance factors were identified in terms of relative importance:

1. Seeking common agreement on how to improve organizational activity

2. Involving members in decision-making in the organization

3. Including project members in decision making within projects.

4. Keeping members of an organization informed of necessary changes and project opportunities.

5. Care for the motivation and activity satisfaction of members of an organization.

The results of the study have shown that NGO leaders tend to seek to involve members of an organization and other participants within ongoing projects in decision-making, as well as to focus attention on other routine management aspects, such as taking care of members' awareness, project opportunities and motivation. Unfortunately, the aspect of improvement is not considered to be highly important. It was only ranked 10th out of 12 priorities on the list, by the study participants. What is more, the first five positions on the list of priorities did not include real world assessment-based solutions which facilitate the improvement of the organization's performance, also enhancement of the quality of organizational performance, perception of the organization's mission, vision and values as well as an in-depth understanding of essential actions. Although the scores of factors 6-9 are slightly lower than those in the first positions, this signals a lack of understanding of NGO leaders of the issue of organizational resilience and allows assuming that regional NGOs are rather poorly prepared to develop their resilience and lack the potential to ensure successful existence of the organization in crises. In turn, insufficient attention to organizational resilience poses threat to not only the survival of NGOs themselves but also the sustainability of regions in the face of socio-economic crises and turbulences. However, this study has several limitations. Firstly, even if the sample size of the study was sufficient to ensure the reliability of the data we can't make categorical statements about the importance of particular resilience factors of NGOs because the number of respondents, representing only the situation of Lithuania, was still quite small. Secondly, due to the lack of studies on the key factors of organizational resilience in NGOs, this study had applied an exploratory design which inhibits an ability to make definitive conclusions about the findings. Therefore, it would be meaningful to replicate the study with a larger number of participants to explore whether the findings of this research would repeat in different contexts. 


\section{References}

1. Austin, J. E. (2010). From Organization to Organization: On Creating Value // Journal of Business Ethics. Vol. 94, No. 1, pp. 13-15. doi: 10.1007/s10551-011-0787-Z

2. Bass, B. M. (2000). The Future of Leadership in Learning Organizations // Journal of Leadership \& Organizational Studies. Vol. 7, No. 3, pp. 1840. doi: 10.1177/107179190000700302

3. Birch, K., Mykhnenko, V. (2009) Varieties of Neoliberalism? Restructuring in Large Industrially Dependent Regions Across Western and Eastern Europe // Journal of Economic Geography. Vol. 9, pp. 355-380. doi: 10.1093/ jeg/lbn058

4. Bluestone, B., Harrison, B. (1982) The Deindustrialization of America: Plant Closings, Community Abandonment and the Dismantling of Basic Industry. Vol. 22, No. 4, pp. 479-782. New York: Basic Books.

5. Boschma, R., Capone, G. (2014). Relatedness, Diversification and Institutions. Working paper, Utrecht University, Utrecht. pp. 1-38.

6. Bristow, G., Healey, A. (2013). Regional Resilience: An Agency Perspective // Journal of Regional Studies. Vol. 48, No. 5, pp. 923-935.

7. Brown, J. S., Duguid, P. (2004). Socialinis informacijos gyvenimas. - Vilnius: Charibdè.

8. Chandra, A., Williams, M., Plough, A., Stayton, A., Wells, K. B., Horta, M., Tang, J. (2013). Getting Actionable about Community Resilience: The Los Angeles County Community Disaster Resilience Project // American Journal of Public Health. Vol. 103, No. 7, pp. 1181-1189.

9. Europos bendrijų komisija (2001). Mokymosi visą gyvenimą memorandumas. - Vilnius.

10. Fraussen, B., Halpin, D. (2017). Think Tanks and Strategic Policy-Making: The Contribution of Think Tanks to Policy Advisory Systems. Research article. Vol. 50, pp. 105-124.

11. Garratt, B. (1987). Learning is the Core of Organisational Survival: Action Learning is the Key Integrating Process. Journal of Management Development. Vol. 6, No. 2, p. 38-44. doi: 10.1108/eb051639

12. Garvin, D. A. (1993). Building a Learning Organization. Harvard Business. Vol. 71, pp. 78-91.

13. Gečienè, J., Raišienè, A. G. (2019). Factors for Strengthening the Organizational Resilience by the Case of Organizations Providing Social
Services. Socialinè teorija, empirija, politika ir praktika. No. 19, pp. 71-86. doi: 10.15388/ STEPP.2019.12

14. Gineitienè, Z., Girdenis, J. (2004). Mažų, vidutinių ir didelių imonių vieta inovacineje veikloje. Organizacijų vadyba: sisteminiai tyrimai. Vol. 30, p. 81-92.

15. Ginevičius, R., Paliulis, N. K., Chlivickas, E., Merkevičius, J. (2006). XXI amžiaus iššūkiai: organizacijų ir visuomenès pokyčiai. - Vilnius: Technika.

16. Grabher, G., Stark, D. (1997). Organizing Diversity: Evolutionary Theory, Network Analysis and Postsocialism // Regional Studies. Vol. 31, pp. 533-544.

17. Haggblade, S., Hazell, P. B. R., Doroh, P. A. (2007). Sectoral Growth Linkages between Agriculture and the Rural Nonfarm Economy. Transforming the Rural Nonfarm Economy. Vol. 7, pp. 141182. doi: $10.1016 / 0305750 x(89) 902325$

18. Jewel, B. R. (2002). Integruotos verslo studijos. Vilnius: The Baltic Press. p. 446.

19. Jucevičius, G. (2007). Inovatyvūs miestai ir regionai. - Kaunas: Technologija.

20. Lane, J. E. (2000). New Public Management. London: Routledge.

21. Lietuvos regioninès politikos baltoji knyga (2017). Darniai ir tvariai plètrai 2017-2030. Pritarta Nacionalinès regioninès plètros tarybos posèdyje 2017-12-15. Internetinè prieiga: https://vrm.lrv.lt/uploads/vrm/documents/ files/LT_versija/Naujienos/Regionines_ politikos_baltoji_knyga_20171215.pdf

22. Lietuvos Respublikos Vyriausybès (2010) m. sausio 20 d. nutarimas Nr. 85 Dèl nevyriausybinių organizacijų plètros koncepcijos patvirtinimo. Valstybės žinios, 2010, Nr. 566.

23. Longworth, N. (2018). Attributes of an Entrepreneurial Learning City Region. Springer International Publishing. pp. 22-42.

24. Magis, K. (2010). Community Resilience: An Indicator of Social Sustainability. International Journal. Society \& Natural Resources. Vol. 23, No. 5, pp. 401-416.

25. Morgan, G. (1998). Images of Organization: The Executive Edition. - San Francisco, CA: BerrettKoehler. pp. 86-118.

26. Norris, F. H., Susan, P., Pfefferbaum, B., Wyche, K. F., Pfefferbaum, R. L. (2008). Community Resilience as a Metaphor, Theory, 
Set of Capacities, and Strategy for Disaster Readiness // American Journal of Community Psychology. Vol. 41, No. 2, pp. 127-150.

27. Pakalniené, R. (2015). Rural Web Method for Revealing a Potential of Rural Development Synergy // Management Theory and Studies for Rural Business and Infrastructure Development. Vol. 37, No. 4, pp. 562-575.

28. Pfefferbaum, B., Reissman, D., Pfefferbaum, R., Klomp, R., Gurwitch, R. (2005). New York: Kluwer Academic Publishers. p. 347-358.

29. Probst, G., Raub, S., Romhardt, K. (2006). Žinių vadyba. Sèkmès komponentai. - Vilnius: Knygiai. 352 p.

30. Punzienè, A. (2002). Profesinio mokymo institucija kaip besimokanti organizacija: problemos ir kaitos gairès. Profesinis rengimas: tyrimai ir realijos. Vol. 4, pp. 74-83.

31. Raipa, A. (2009). Šiuolaikinio viešojo valdymo pokyčių kryptys ir tendencijos. Viešoji politika ir administravimas. Vol. 30, p. 22-32. - Vilnius, MRU.

32. Recommendation CM/Rec (2007). 14 of the Council of Europe Committee of Ministers to member stateson the legal status of nongovernmental organisations in Europe. Adopted by the Committee of Ministers on 10 October 2007 at the 1006th meeting of the Ministers' Deputies. HDIM.IO/59/08.

33. Reed, A. M., Reed, D., (2009). Partnerships for Development. Four Models of Business Involvement. J. Bus. Ethics. Vol. 90, No. 1, pp. 3-37.

34. Rosset, P. M., Martínez-Torres, M. E. (2012). Rural Social Movements and Agroecology: Context, Theory, and Process // Journal Ecology and Society. Vol. 17, No. 3, pp. 1-13. doi: 10.5751/ES-05000-170317

35. Senge, Р. (1999). Пятая дисциплина. - Москва. ЗАО: Олимп-Бизнес.
36. Senge, P. McCabe, N., Lucas, T., Smith, B. Dutton, J., Kleiner, A. (2000). Schools that Learn; A Fifth Discipline Resource. - New York: Doubleday Dell Publishing Group.

37. Šilinskytè, A. (2013). Nevyriausybinių organizacijų veikla ir vaidmuo Lietuvoje. Viešoji politika ir administravimas. Vol. 12, No. 2, pp. 326-338.

38. Simonaitienè, B. (2003). Mokykla - besimokanti organizacija. - Kaunas: Technologija.

39. Smith, M. K. (2001). Peter Senge and the Learning Organization. The Encyclopaedia of Informal Education.

40. Swanstrom, T. (2008), Regional Resilience: A Critical Examination of the Ecological Framework. - University of California Berkeley, Institute of Urban and Regional Development (IURD) Vol. 25, No. 07, pp. 1-34.

41. Valstybès kontrolè (2008). Valstybinio audito ataskaita, Viešojo ir privataus sektoriaus bendradarbiavimas, p. 48.

42. Wholey J. (1983). Evaluation and Effective Public Management. - Boston: Little Brown and Co. pp. 157-158.

43. Williams, N., Vorley, T., Ketikidis, P. H. (2013) Economic Resilience and Entrepreneurship: A Case Study of the Thessaloniki City Region // Journal Local economy. Vol. 28, No. 4, pp. 399415. doi: 10.1177/0269094213475993

44. Wolfe, D. A. (2010), The Strategic Management of Core Cities: Path Dependence and Economic Adjustment in Resilient Regions // Journal of Regions, Economy and Society. Vol. 3. pp. 139152. doi: $10.1093 /$ cjres/rsp032

The paper submitted: May 20, 2020

Prepared for publication: December 10, 2020

\section{Jolita GEČIENĖ, Agota Giedrè RAIŠIENĖ, Violeta RAPUANO}

\section{ORGANIZACIJŲ ATSPARUMAS: AR JIS ATITINKA BESIMOKANČIOS ORGANIZACIJOS PRINCIPUS?}

\section{S a n t r a u k a}

Turbulentiški pokyčiai socioekonominèje aplinkoje kelia iššūkius ne tik organizacijų, bet ir šalių bei jų regionų atsparumui ir tvarumui. Pabrèžtina, kad šalies tvarumas taip pat priklauso nuo regionuose veikiančių organizacijų atsparumo. Pastebima, kad esant nenumatytoms aplinkybèms ir krizinèms sąlygoms daugiau iššūkių patiria nuo regioninių centrų nutolusios organizacijos, nes politikos formuotojai daugiausiai demesio sutelkia šalies centriniams 
regionams ir ten veikiančioms organizacijoms, todèl organizacijų, nutolusių nuo regionų centrų, atsparumo stiprinimas tampa aktualia problema.

Šio straipsnio tyrimo objektas - organizacijų atsparumas.

Straipsnio tikslas - besimokančios organizacijos kontekste išryškinti svarbiausius organizacijų atsparumo veiksnius.

Straipsnyje apžvelgti organizacijų tipai, aptartos organizacijų atsparumo ir besimokančios organizacijos sąsajos, atskleisti organizacijų atsparumo svarbiausi veiksniai.

Tyrimo duomenų analizè atlikta naudojant santykinès svarbos indekso (RII) vertinimo metodą.

Pirmoje straipsnio dalyje charakterizuojama organizacijų ìvairové, aptariama nuo regiono centro nutolusių organizacijų problematika. Antroje straipsnio dalyje analizuojamas organizacijų atsparumas besimokančių organizacijų kontekste, pagrindžiamas besimokančių organizacijų pranašumas jų atsparumo atžvilgiu. Trečioje straipsnio dalyje išryškinami organizacijų atsparumo veiksniai teoriniu požiūriu. Empirinèje dalyje pristatomi Lietuvos rajoninèse (ne didžiųų miestų) savivaldybèse ir kaimiškosiose vietovèse veikiančių NVO vadovų apklausos rezultatai. Remiantis apklausos rezultatais respondentų ívardinti organizacijų atsparumo veiksniai ranguojami pagal santykinę svarbą, formuluojamos įžvalgos teorinès analizès kontekste.

Remiantis tyrimo rezultatais daroma išvada, kad nuo regionų centrų nutolusios NVO, esant nenumatytoms aplinkybėms ir krizinems situacijoms, labiau linkusios rūpintis rutininiais vadybiniais klausimais, igalinančiais organizacijos narius veiksmingai bendrauti ir bendradarbiauti kartu siekiant NVO veiklos rezultatų. Svarbiam organizacinio atsparumo veiksniui - organizacijos narių tobulinimui(uisi) - NVO vadovai linkę teikti vieną iš mažiausių prioritetų. 